\title{
THE ARCHETYPE OF THE WOMAN IN THE LIFE AND WORK OF PAUL EVDOKIMOV
}

\author{
K A R E L SLÁ D E K
}

\begin{abstract}
The article presents the view of the Russian Orthodox theologian Paul Evdokimov on the topic of women. Evdokimov's theological reflections are framed in his own experience with women. The first chapter on the role of woman as mother as the inspiration of the icons of the Mother of God and God's Wisdom begins with the mention of Evdokimov's beautiful relationship with his own mother who gave him religious faith. He could not perceive a woman other than through this experience of maternal love. As an Orthodox thinker, he put the theme of woman as fiancée and wife in the sacramental unity of man and woman, modelled on the love of Christ and the Church, as discussed in the second chapter. The third chapter, again, deepens the topic in the example of the archetype of the woman as the Mother of God, and the archetype of the man as John the Baptist from the Deisis icon. The second and third chapters also mention his pain in the death of his first wife and his second marriage, which gave him the power to create. Evdokimov was critical of the history of subjugating women to men through ideologies, philosophies, and religions. Against this, he stressed that, in a Christian perspective, the woman, through her religious nature, is the stronger sex.
\end{abstract}

Keywords

Paul Evdokimov; Orthodoxy; Woman; Archetype; Icon

DOI: $10.14712 / 23363398.2020 .60$

P aul Evdokimov (1901-1970) was one of the most famous Orthodox Russian theologians among the 20th-century laity. He became the 'voice of Orthodoxy' in the West as he had emigrated to France after the Bolshevik coup. As a lay theologian, he dealt with the spirituality of the Christian layman, sacramental theology from a spiritual point 
of view - especially the sacrament of marriage, and, finally, orthodox theology in openness to ecumenical efforts. Evdokimov was an active advisor to the Second Vatican Council and influenced some of its publications. The culmination of his work is the theology of beauty as analysed primarily in Orthodox icons. ${ }^{1}$

One reason he was especially interested in theological reflections on the question of women can be found in his reading of the signs of the times, understanding the woman's question - Do we want a woman's revolution? - as a challenge to the Church and trying to discern its spiritual dimension. He focused on the interdependence and complementary nature of female and male charismas, viewing man and woman through theological and spiritual lenses. The reductive approach, which analyses woman and man through mere biological conditionality without reflecting the spiritual goals of femininity and masculinity, was perceived as leading to distorted conceptions due to the fall of man. His reflections on woman put the subject within theological anthropology, into liturgical, biblical, dogmatic, iconic, and mystical perspectives. ${ }^{2}$

Evdokimov, however, was not only focused on theological trends of the past, especially in Orthodoxy, but also pursued the possibilities of enriching theology with knowledge of the humanities. He especially liked Jungian psychology and its concept of archetypes, which afforded him the necessary space to deepen the subject from a theological perspective. Here we need to make an initial distinction that Evdokimov was aware of: For Jungian psychology, in the process of identification, one consciously realises himself as a persona who selects from the collective unconscious the possibilities of his realisation - to an awareness of his essential Self. Man seeks 'models' and 'roles' of femininity and masculinity. Archetypal masculine and feminine images (anima, animus, mother, father, virgin, prostitute, etc.) are the mechanisms of communication between the conscious and unconscious, both being part of the collective unconscious. Thus, masculinity is a conscious part of the soul of a man and femininity that of a woman, while the man has

1 Cf. Karel Sládek, Cesty k boholidství(Červený Kostelec: Pavel Mervart, 2012), 157-177. For a more detailed overview of Evdokimov's life and work see Olivier Clément, Orient-Occident. Deus passeurs: Vladimir Lossky et Pavel Evdokimov (Genève: Labor et Fides, 1985), 105-190; Jean-François Roussel, Pavel Evdokimov. Une foi en exil (Montréal: Médiaspaul, 1999); Giorgio Celora, Evdokimov. Voce dell ortodossia in Occidente (Bologna: EDB, 1996).

2 Cf. Olivier Clément, 'Předmluva', in Žena a spása svéta, Pavel Evdokimov (Olomouc: Refugium Velehrad-Roma, 2011), 5-8. 
an unconscious soul of femininity and a woman of masculinity. These theories do not make a clear distinction as to whether genetic or cultural conditionality is involved in the archetype realisation. Carl G. Jung himself was ambiguous on this issue. ${ }^{3}$ At the same time, Jung did not answer the question of whether the archetypes are merely immanent to the human soul or have an objective, transcendental dimension. As a psychoanalyst, he was not interested in the philosophical or theological interpretation of the archetype, thus offering room for theologians to contribute. Evdokimov accepted the challenge and pointed out that the Christian tradition has creative archetypes for understanding the spiritual role of woman and man. On the one hand, man is born with biological conditionality, but he also becomes a woman and a man and this is helped in the Christian interpretation by archetypes displayed, for example, on icons. For Evdokimov, archetypes are not only psychological but also ontological and dogmatic. ${ }^{4}$

It should be mentioned in the introduction that Evdokimov's theology of women was framed within his own experience with his mother and wives. Thus, the aim of the article is not to compare the views on Evdokimov's work with other authors or to confront his ideas with contemporary feministic (and theological) approaches or gender questions. The chosen method is not comparative, but it is primarily anchored in the methodology of spiritual theology. The main question thus is how Evdokimov's reflection about a woman mirrors his own spiritual theology based on the Revelation of Scripture, Orthodox tradition, the conclusions of contemporary human sciences, and especially his own Christian (sacramental) experience of life in marriage. The following text will follow the stages of his creative life, while mother-son, wife-husband relationships will be placed within the context of his theological considerations. Evdokimov loved his mother very much. He also suffered pain while attending to his dying first wife and was then married a second time. It was during these times that his core works on women were formed. The following is divided into three stages: woman as the archetypal mother in the icons of the Mother of God; woman as fiancée and wife in the sacramental perspective; and woman as a sign of salvation in the Deisis icon.

3 Cf. Patrick Vandermeersch, 'Archetypy: nová cesta ke svatosti', in C. G. Jung a krestáanská spiritualita, ed. Robert L. Moore (Praha: Portál, 1998), 118-132.

4 Cf. Paul Evdokimov, 'C. G. Jung at la Téologie', Contacts no. 40 (1962): 34-48. 


\section{Woman as Archetypal Mother in Mother of God icons}

As Evdokimov considered the archetype of woman as mother inspired by the icons of the Mother of God, then we will surely find many connections to his own experience in the relationship of mutual love with his mother. Paul Evdokimov grew up with only his mother, having lost his father, a nobleman and an officer who had been assassinated, at age six. His childhood and adolescence were spent in the care of his mother. He always remembered with love the beautiful religious atmosphere his mother had created at home. Thanks to his mother, he became aware of his belief in the presence of God in every moment. His religious ideas were shaped by the great Russian writers, especially Fyodor M. Dostoevsky. Following the family tradition, he entered cadet school but soon recognised his calling as a theologian. His studies at the Theological Academy in Kiev were interrupted by the Bolshevik coup and his forced exile to Paris. ${ }^{5}$ His interrupted relationship with his home was replaced by the study of Orthodox theology. ${ }^{6}$ He was also inspired by the theology of the beauty of icons, which, according to our theme, played an important role in expressing the maternal side of God the Father in a woman through the work of the Holy Spirit.

His sensitivity to the archetype of woman as mother manifested itself in his descriptions of icons depicting the Virgin Mary. When he considered one of the most popular Marian icons in Russia known as the Icon of the Mother of God Vladimirskaya, he opened his reflection by meditating upon the role of the woman and her spiritual mission. Our Lady freely accepts the work of the Holy Spirit in her life. Thus, God no longer acts outside man but within him. By opening herself to the infinite love of God, Mary she conceived a Son. As Evdokimov states, this icon combines two types of Marian icons: 'She that points the way' and 'The Tender Virgin'. He follows the delicate depiction of the hugs of Mother and Child. The child's view of the mother is that of tenderness and comfort. The mother's face speaks of maternal love. At the same time, her great eyes of open eternity are turned inward. Mother's eyes follow the fate of every person. ${ }^{7}$ In his appeal to the archetype of woman

5 Cf. Maria R. Langella, 'Pavel Nikolajevič Evdokimov (1901-1970)', in Credere oggi. Teologi ortodossi del $X X$. secolo, 2 (III-IV, 2004), 75-83.

6 Cf. Paul Evdokimov, Le buisson ardent (Paris: P. Lethielleux, 1981).

7 Cf. Pavel Evdokimov, L'art de l'icône: théologie de la beauté (Paris: Desclée de Brouwer, 1970), 221. 
as mother, Evdokimov wanted to emphasise the beauty of the unique relationship between mother and child which should not retreat into the background, while reflecting upon the role of the woman.

The symbolism of the icons is related to another, somewhat forgotten archetype of the woman inspired by the title, Mary: Woman as Wisdom. In this book, he recalled the Icon of God's Wisdom, in which, in his words, one can see a deep mystery. God's Wisdom is depicted in the Novgorod icon as an angel sitting on the throne. Behind the angel stands Christ, who places his hands on the angel. In the theological tradition, not only Christ, the Holy Spirit, the uncreated energies of the Trinity, and the Church, but also the Virgin Mary was considered to be an angel. According to Evdokimov, Wisdom encompasses all interpretations. The Virgin Mary became the embodied Wisdom as a privileged place for the Incarnation. The interconnection of Mary with Christ, the Holy Spirit, with the action not created by the energies of the Trinity, and with the Church creates a space for understanding the role of the mother's woman in the religious perspective and in the life of the Church. ${ }^{8}$ The archetypal integrity of the woman is depicted in the icon as ontological purity, beauty, and maternal tenderness. ${ }^{9}$

A mother can fulfil not only the desire for the love of a particular person but also the desire for God and religious experience focused on the ultimate goal of man. Following the example of Mary, the woman is open to meeting God and man in a relationship of love. ${ }^{10}$ Surely we will not be far from the truth by stating that, for Evdokimov, his own mother represented the archetype of Wisdom-Mary-Church.

\section{Woman as Fiancée and Wife in Sacramental Perspective}

Just as in the case of Evdokimov's wife-mother archetype, where his theological reflection was connected with the experience of his own mother's love, so in the case of a woman's archetype as fiancée and wife he was influenced by the experience of mutual love with his wife. His first wife was Natacha Brunel from a mixed French-Russian family. ${ }^{11}$

\footnotetext{
Cf. ibid., 293-300.

Cf. Giorgio Celora, Evdokimov (Bologna: EDB, 1996), 241.

Cf. Marco Paleari, Il sacramento dell' eros. Una lettura simbolico-sapienziale dell' eros benedetto a partire da V. S. Solov'ëv e P. Evdokimov (Roma: Pontificio Seminario Lombardo, 2003), 226-229.

11 Cf. Jean-François Roussel, Paul Evdokimov (Paris: Médiapaul, 1999), 15.
} 
He had two children with her, Nina and Michal. Evdokimov fully devoted himself to his family. His wife, however, developed cancer and died prematurely. As a loving husband, he accompanied her through the last moments of her life. In addition to his dissertation work, he focused primarily on the children and his household. ${ }^{12}$ During this painful time, he focused on the topic of marriage and matrimonial love as a reflection of eternal unity.

In 1944, the year before the death of his first wife, he published the book Marriage, The Sacrament of Love, which he later edited and updated slightly as The Sacrament of Love with the subtitle Wedding Secrets in the Light of Orthodox Tradition. As a theologian, he came out of the spiritual interpretation of the Sacrament of Marriage as it is liturgically experienced in the Orthodox tradition. Before he touched upon the mystery of the Sacrament of Marriage, he realistically stated that the original paradise of the unity between man and woman had been torn. The man, in his interpretation, fell into pure reasoning, creating abstractions, and wanting to overcome every limitation. Among the limitations seems to be the overcoming of the relationship with a woman, thus losing the awareness of the need for the complementarity. The woman is perceived by the man as an inferior maid. Thus 'Adam's complex' is also manifested by the fact that the woman is to blame for everything - and the man embarks on a cursed path. After a historical analysis of the woman's subordination, he presents the fundamental charisma of a woman: Through her being, she can relate everything to God. Thus, she becomes a spiritual mother with overlap into eternity. The woman is saved by her motherhood in terms of the birth of a new age, aeon, eschatological holiness. In relation to a man, her love stands out because she loves him as he is and seeks to fulfil his need for love. The man wants to dream his need for love and often falls into overly romanticised ideas. A man wants to act while a woman wants to be - and thus bring everything to God. When Evdokimov continues to point out the differences between men and women, he does not want to confront them but, on the contrary, wants to emphasise that only in the complementary nature of man and woman can a man unite. A mysterious unification occurs in the Sacrament of Marriage. According to Evdokimov, marriage is new, an ontological creation that

12 Cf. Václav Ventura, 'Kniha, která změnila můj život,' in Epochy duchovního života, Pavel Evdokimov (Olomouc: Refugium Velehrad-Roma, 2002), 5-19. 
feeds human time forever. ${ }^{13}$ Marriage underscores its spiritual and theological meaning.

The section Love and the Sacrament of Love goes into the depths of the meaning of love. Since man was created in the image of God as a unity of man-woman, the goal of the sacrament of marriage is to restore God's image by reuniting man and woman in the sacrament of marriage, which had already been established in paradise. It is the fulfilment of this mystery, the lost paradise of unity in the sacrament of marriage, that is more important to Evdokimov (who had been inspired by John Chrysostom) than the task of having children. Thus, there is also a spiritual sense of marriage in which husbands cannot bear children, even if they wish. In the New Testament perspective, the aim of conjugal love is to restore spiritual unity between man and woman, which is as strong as the unity in the relationship of love between Christ and the Church. The man in marriage represents Christ, and the woman represents the Church. In the Byzantine Rite Liturgy, during the celebration of the Sacrament of Marriage, this unity is emphasised by the so-called coronation of the spouses and the joyful 'dance' with the priest around the altar. Evdokimov sees every woman's vocation in Our Lady as the central archetype of the Church: 'The cult of the Virgin Mother expresses the vocation of every woman, her charisma of protection and care', ${ }^{14}$ and a woman lay dying as he wrote these lines.

\section{Woman as a Sign of Salvation on the Deisis Icon}

Another woman in his life stood at the conception of Evdokim's reflection on women. He married, for the second time, the considerably younger Tomoto Sakai from a Japanese-English family. His second wife brought him to a new creative endeavour. His first book after his marriage could not concern any topic other than women. ${ }^{15}$

In 1958, Evdokimov published a sequel to his first book about a woman: The Sacrament of Love in the monograph Woman and the Salvation of the World. In the second part of the book, he opened the above-mentioned topic of masculine and feminine archetypes, the

13 Cf. Pavel Evdokimov, Sacrement de l'amour: le mystère conjugal à la lumière de la tradition orthodoxe (Paris: Editions de l'Epi, 1962), 60.

14 Ibid., 168.

15 Cf. Olivier Clément, Orient-Occident Deus Passeurs: Vladimir Lossky, Paul Evdokimov (Genève: Labor et fides, 1985), 114-115. 
animus and anima in the human soul, which are for him the biblical Adam and Eve - who dwell in our collective unconscious. According to the biblical narrative, man as the archetype of all humanity was created in the initial unity of man-woman. Man and woman cannot be understood as two completely separate and isolated individualities. Each person is created for reciprocity and face-to-face sharing. In the narrative of the fall and the tearing apart of Adam and Eve's unity with God, the polarisation between man and woman arose, with increasing consciousness, between master and servant, and 'nothing will prevent a woman from appearing to a man merely as an object of pleasure or oppressive power. ${ }^{16}$ As a Christian theologian, Evdokimov saw the consequences of the fall in the light of sharing Jesus Christ because, as inspired by Pauline theology, there is no longer a man or a woman in Christ. Evdokimov is aware of the importance of emphasising God as the Father of the Almighty, the Saviour and the Comforter, with the centre of Revelation in the Father-Son relationship. Paradoxically, however, it emphasises the importance of the virginity of the Virgin in the salvation of the world, which is more in keeping with spiritual paternity than male conquerors, adventurers, and builders who do not have the 'paternal instinct as strong as the maternal woman'. ${ }^{17}$ The echo of God's fatherhood is human motherhood.

The theologian goes even further into some very original ideas in which he claims that secularisation is a manifestation of the masculinisation of society, and that atheism is also essentially masculine, as well as Kant's rational ethics that ironise love or Augustine's sarcasm about love with rigid attitudes towards women. On the other hand, intuitive philosophy, an emphasis on emotional knowledge, and saints consecrated to the Mother of God testify to the true face of religion and the mother principle in ethics, manifested in purity, self-sacrifice, and the protection of the weak. In the contemporary world, it is the woman who has become the protector of religious values. In religious terms, therefore, the woman is the stronger sex. ${ }^{18}$

But the woman herself has some degree of bipolarity due to the fall. The archetype of the woman is Eve, who has two faces facing each other at the end of time: a prostitute in Babylon and a woman dressed in

16 Paul Evdokimov, La femme et la salut du monde (Paris: Casterman, 1958), 142.

17 Ibid., 148.

18 Cf. ibid., 148-154. 
the sun. This apocalyptic scene inspired Evdokimov to analyse the feminine revolution that was taking place before his eyes. The first image of a woman smells of nothingness. She is a masculine woman who seeks to come to terms with men and therefore takes on male vices and sins. Certain currents of the emancipation movement produce an aggressive and biased woman who neglects her children. Yet he was aware of the importance of the woman's spiritual revolution. In the book, he again reveals the history of women's subordination in dualistic philosophies where a woman is a passive and evil entity. He also recalled rabbinic anti-feminism and the ascetic singularity of some monks, Gnostics, and sectarians who saw salvation escaping from all women and perceived redemption as a deliverance from their sexuality, with a negative view of marriage as 'satanic repugnance'. ${ }^{19}$ As noted, Evdokimov defended the sacrament of marriage and interpreted the woman's revolution as a spiritual challenge for the religious revival of society.

Then, looking toward his own archetypes of masculinity and femininity, with a view to relate both to Christ, he found them in the Orthodox tradition of icons. In the group of icons called Deisis, Christ is placed in the centre and, to the left and right of him, by the inclination of Christ, the Mother of God and John the Baptist intercede, or further, angels, apostles, and other saints. ${ }^{20}$ The archetype of femininity becomes the Mother of God, and the archetype of masculinity is John the Baptist. The importance of the Mother of God was included by Evdokimov in the event of the Incarnation as a common and free work of God the Father in the power of the Holy Spirit and the Virgin Mary. Mary revealed the archetypical fullness of humanity, holiness, and glory in the sense that the ultimate purpose and the purpose of all deification took place. Mary agreed with the Incarnation of her body and was likewise present at the descent of the Holy Spirit on the Pentecost. For humanity, she set the path and pointed the direction for Christ to the New Jerusalem.

It can be said that femininity is inherently embedded in the sign of the Birth and Pentecost, the sign of the birth of a new creation and a new age. Masculinity is energetic - under the sign of the Resurrection, Transfiguration, and Parousia. The divine world marked by the sign of the Father

19 Cf. ibid., 162-164.

20 Cf. Jiří Novotný, Svétlo ikon (Olomouc: Refugium Velehrad - Roma, 1997), 69-70. 
corresponds to the human world marked by the sign of the Mother. This means that the human world is maternal in the function of its virgin structure. ${ }^{21}$

In this quotation, femininity refers to masculinity and motherhood to the fatherhood of God the Father. As the archetype of the man in the composition Deisis, Evdokimov chose a figure on the opposite side next to Christ: John the Baptist. For him, Mary and John the Baptist are the archetypal integration of femininity and masculinity into Christ. Christ in the icon has a priest's insignia, blesses, and serves as a judge. John the Baptist is the Forerunner whose birth is also proclaimed, an ascetic, a friend of the Bridegroom who recognised Christ as the Lamb and who paves the way for Christ's second coming. It is the presence of a prophetic charisma that is sensitive to God's presence. ${ }^{22}$ Thus, a man should also spiritually become a forerunner, an ascetic, a friend of Christ, a prophet.

In Christ, everything is united by the fall of the split, and the division into the soul of man also unites. For Evdokimov, every soul is a picture of Deisis; it contains the Mother of God and John the Baptist, being 'at the same time a servant and friend of the Bridegroom'. ${ }^{23}$ Originally, a violent man serves the liturgy in this temple. Again, there is marital unity following the example of the love of Christ and the Church.

\section{Conclusion}

This article reflects the archetype of the woman in the life and work of Paul Evdokimov. Methodologically, Evdokimov drew from Carl G. Jung's knowledge and his doctrine of archetypes. He gave the archetypes a theological interpretation and turned them into the topic of female and male spirituality. Archetypes such as mother or prostitute have acquired biblical content: the mother as the Mother of God and the prostitute as the end-of-time prostitute from an apocalyptic perspective. Evdokimov appreciated the importance of the women's revolution. He sought to support women's efforts to break free from stereotypes and to offer a treatise on the true, spiritual charisma

21 Paul Evdokimov, La femme et la salut du monde, 218.

22 Cf. ibid., 222-243.

23 Ibid., 247. 
of the woman, in which the woman stands out above men. In the motherhood of the woman, he saw the reflection of God the Father more than men. He became a defender of women and greatly respected them in his private life.

Hnilickova 471

53701 Chrudim 2

Czech Republic

E-mail: karel.sladek@centrum.cz 